\title{
Oxidation of black carbon by biotic and abiotic processes
}

\author{
Chih-Hsin Cheng ${ }^{\text {a }}$, Johannes Lehmann ${ }^{\mathrm{a}, *}$, Janice E. Thies ${ }^{\mathrm{a}}$, \\ Sarah D. Burton ${ }^{\mathrm{b}}$, Mark H. Engelhard ${ }^{\mathrm{b}}$ \\ a Department of Crop and Soil Sciences, Cornell University, 909 Bradfield Hall, Ithaca, NY 14853, USA \\ ${ }^{\mathrm{b}}$ Environmental Molecular and Sciences Laboratory, Pacific Northwest National Laboratory, Richland, WA 99352, USA
}

Received 27 January 2006; received in revised form 19 May 2006; accepted 28 June 2006

Available online 22 August 2006

\begin{abstract}
The objectives of this study were to assess the relative importance of either biotic or abiotic oxidation of biomassderived black carbon $(\mathrm{BC})$ and to characterize the surface properties and charge characteristics of oxidized $\mathrm{BC}$. We incubated $\mathrm{BC}$ and $\mathrm{BC}-$-soil mixtures at two temperatures $\left(30^{\circ} \mathrm{C}\right.$ and $\left.70{ }^{\circ} \mathrm{C}\right)$, with and without microbial inoculation, nutrient addition, or manure amendment for four months. Abiotic processes were more important for oxidation of $\mathrm{BC}$ than biotic processes during this short-term incubation, as inoculation with microorganisms at $30^{\circ} \mathrm{C}$ did not change any of the measured indicators of surface oxidation. Black $\mathrm{C}$ incubated at both $30{ }^{\circ} \mathrm{C}$ and $70{ }^{\circ} \mathrm{C}$ without microbial activity showed a decrease in $\mathrm{pH}$ (in water) from 5.4 to 5.2 and 3.4, as well as an increase in cation exchange capacity (CEC at $\mathrm{pH} 7$ ) by $53 \%$ and $538 \%$ and in oxygen $(\mathrm{O})$ content by $4 \%$ and 38\%, respectively. Boehm titration and Fourier-transform infrared (FT-IR) spectroscopy suggested that formation of carboxylic functional groups was the reason for the enhanced CEC during oxidation. Analysis of surface properties of BC using X-ray photoelectron spectroscopy (XPS) indicated that the oxidation of $\mathrm{BC}$ particles was initiated on the surface. Incubation at $30^{\circ} \mathrm{C}$ only enhanced oxidation on particle surfaces, while oxidation during incubation at $70^{\circ} \mathrm{C}$ penetrated into the interior of particles. Such short-term oxidation of BC has significance for the stability of $\mathrm{BC}$ in soils as well as for its effects on soil fertility and biogeochemistry.
\end{abstract}

(C) 2006 Elsevier Ltd. All rights reserved.

\section{Introduction}

Annual production of biomass-derived black carbon (BC in this contribution) by vegetation burning is significant and is estimated to be $50-270 \mathrm{Tg} \mathrm{C}$ year $^{-1}$ (Kuhlbusch and Crutzen, 1995). Compared to non-BC, BC produced during forest fires or for bio-char production has lower biological availabil-

\footnotetext{
* Corresponding author. Tel.: +1 607254 1236; fax: +1 607255 3207.

E-mail address: CL273@cornell.edu (J. Lehmann).
}

ity in soils, but actual determined rates of mineralization are still scarce (Bird et al., 1999; Baldock and Smernik, 2002). Due to the resulting long residence time, BC is an important stable $\mathrm{C}$ pool in soils and sediments (Schmidt and Noack, 2000). Although BC is often considered to be biological "inert", it is clear that it is oxidized and finally mineralized to $\mathrm{CO}_{2}$ over long periods of time (Goldberg, 1985). High-temperature aerobic oxidation (Morterra et al., 1984; Toles et al., 1999) reactions with strong chemical oxidants (Moreno-Castilla et al., 2000), or ozone oxidation (Sergides et al., 1987; Kawamoto 
et al., 2005) have shown that BC can be abiotically oxidized over short periods of time. However, shortterm oxidation under ambient temperature and atmosphere has not yet been recognized and sufficiently quantified, and the extent of both abiotic and biotic oxidation is unclear. Some research has indicated that oxidation may occur through abiotic chemisorption of oxygen $(\mathrm{O})$ by aging processes (Puri, 1963, 1970; Billinge and Evans, 1984; Adams et al., 1988). On the other hand, microbial oxidation may also play a role in short-term oxidation of $\mathrm{BC}$, but few results that have investigated controls on its decomposition in incubation studies (Shneour, 1966; Baldock and Smernik, 2002; Hamer et al., 2004) or in the soil environment (Shindo, 1991; Petsch et al., 2001) are available. In general, such oxidation processes can lead to an oxygenated surface on BC (Boehm, 1994), forming carboxylic, phenolic, hydroxyl, carbonyl, or quinone $\mathrm{C}$ forms, and change the amphoteric characteristics (Lau et al., 1986).

As BC in soil is present as particles, albeit of very small size of mostly below $<53 \mu \mathrm{m}$ (Skjemstad et al., 1996), oxidation may first begin on particle surfaces (Lehmann et al., 2005). Oxidation of such particles may lead not only to mineralization of this highly stable form of organic $\mathrm{C}$ in soil, but may create negatively-charged surfaces, consequently leading to greater cation exchange capacity (CEC) and nutrient retention in soil (Glaser et al., 2002; Liang et al., 2006). The factors controlling this surface oxidation are important for the biogeochemistry of soil ecosystems, but have not been studied.

The objectives of this study were to quantify the relative importance of biotic or abiotic oxidation of $\mathrm{BC}$ and to characterize the surface properties of oxidized particulate $\mathrm{BC}$. The hypotheses to be tested were: (1) oxidation is affected to a greater extent by biotic than by abiotic processes, and (2) oxidation is more pronounced on surfaces than in the interior of $\mathrm{BC}$ particles.

\section{Materials and methods}

\subsection{Experimental}

Biomass-derived BC was produced from black locust (Robinia pseudoacacia L.). The bark was removed from the air-dried logs and the wood was cut into pieces $3 \mathrm{~cm}$ by $2 \mathrm{~cm}$. These were put into tin containers, which were loosely sealed with a lid and combusted in a muffle furnace at $350^{\circ} \mathrm{C}$ for
$16 \mathrm{~h}$. The average recovery of $\mathrm{BC}$ was $33.2 \%$ by mass (SE $1.7 ; N=65$ ). It was then ground to pass a $2 \mathrm{~mm}$ sieve. To reduce the ash and tar contents, the particles were repeatedly leached with deionized water until the electric conductivity of the leachate (1:3 w/v) was below $50 \mu \mathrm{S} \mathrm{dm}{ }^{-1}$. Subsequently, the particles were dried at $60{ }^{\circ} \mathrm{C}$ for $24 \mathrm{~h}$ and stored in a desiccator.

The $\mathrm{BC}$ was incubated at two temperatures $\left(30^{\circ} \mathrm{C}\right.$ and $\left.70^{\circ} \mathrm{C}\right)$, with and without microbial inoculation (mic; only for $30^{\circ} \mathrm{C}$ ), with and without inorganic nutrient addition (F), and with and without manure amendment (man). The experiments were conducted using only $\mathrm{BC}$ in comparison to a BC-soil mixture with $2 \mathrm{~g} \mathrm{BC}$ and $50 \mathrm{~g}$ soil in $250 \mathrm{~mL}$ bottles. The microbial inoculum was a commercial product (BIOMEX OM-X, a pro-biotic soil restorer from Biomex Inc., Melbourne, Australia) to provide sufficient microbial activity during incubation. We pre-incubated the inoculum with water and then transferred the filtered cultures to the treatments receiving microbial inoculation.

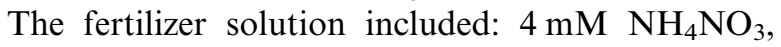
$4 \mathrm{mM} \quad \mathrm{CaCl}_{2}, 2 \mathrm{mM} \quad \mathrm{KH}_{2} \mathrm{PO}_{4}, 1 \mathrm{mM} \quad \mathrm{K}_{2} \mathrm{SO}_{4}$, $1 \mathrm{mM} \quad \mathrm{MgSO}_{4}, 25 \mu \mathrm{M} \quad \mathrm{MnSO}_{4}, 2 \mu \mathrm{M} \quad \mathrm{ZnSO}_{4}$, $0.5 \mu \mathrm{M} \mathrm{CuSO} 4$ and $0.5 \mu \mathrm{M} \mathrm{Na} \mathrm{NoO}_{4}$, of which $2 \mathrm{~mL}$ were added to each incubation jar. The manure was obtained from a local dairy farm and $2 \mathrm{~g}$ were added. All bottles with the materials to be incubated were sterilized using $\gamma$ irradiation before microbial inoculation in order to avoid an experimental artifact through irradiation. The soil was a subsoil horizon taken from an Anionic Acrustox from the Brazilian Cerrado savanna (Martinez et al., 2001). The BC and BC-soil mixtures were kept at $50 \%$ water holding capacity and were incubated for 4 months using a randomized complete block design with 4 replicates.

\subsection{Chemical analysis}

The $\mathrm{pH}$ in water and $1 \mathrm{~N} \mathrm{KCl}$ solution was measured at 1:20 (w/v) ratio for $\mathrm{BC}$ samples and 1:2.5 $(\mathrm{w} / \mathrm{v})$ ratio for $\mathrm{BC}-$-soil mixtures after occasionally stirring over $1 \mathrm{~h}$. The exchangeable acidity was analyzed with $1 \mathrm{~N} \mathrm{KCl}$ extraction for $1 \mathrm{~h}$ and titrated with 0.005 and $0.025 \mathrm{~N} \mathrm{NaOH}$ solution for $\mathrm{BC}$ and $\mathrm{BC}-$ soil mixtures, respectively. The exchangeable $\mathrm{Al}$ was determined in the $\mathrm{KCl}$ extract by adding $1 \mathrm{~N} \mathrm{KF}$ to react with the $\mathrm{Al}$ and Al-hydroxides and then back titrating with $0.01 \mathrm{~N} \mathrm{HCl}$ solution. The potential CEC was measured by saturating the 
exchange sites of $0.8 \mathrm{~g} \mathrm{BC}$ or $2.5 \mathrm{~g} \mathrm{BC}$-soil mixtures with $40 \mathrm{~mL} 1 \mathrm{~N}$ ammonium acetate at $\mathrm{pH} 7$ twice and by consecutively replacing the adsorbed ammonium ions by $2 \mathrm{~N} \mathrm{KCl}$. The ammonium was measured using a segmented flow analyzer (Technicon Auto Analyzer, Chauncey, CT, USA).

Analyses of $\mathrm{C}$, hydrogen $(\mathrm{H})$ and $\mathrm{O}$ and stable isotopes were done at the Stable Isotope Facility, University of California, Davis, CA. Carbon isotopes were measured for $\mathrm{CO}_{2}$ using dry combustion analysis coupled to an on-line isotope ratio mass spectrometer (PDZ Europa ANCA and 20-20 mass spectrometer, Sercon Ltd., Crewe, UK). Hydrogen and $\mathrm{O}$ stable isotopes ( $\delta \mathrm{D}$ and $\delta{ }^{18} \mathrm{O}$, respectively) were measured after sample conversion to $\mathrm{H}_{2}$ and $\mathrm{CO}$ at $1400^{\circ} \mathrm{C}$ over glassy $\mathrm{C}$ (Hekatech TCEA, Hekatech $\mathrm{GmbH}$, Wegberg, Germany; and PDZ Europa 20-20 isotope ratio mass spectrometer, Sercon Ltd., Crewe, UK).

Boehm titration (Boehm, 1994) was used for quantifying various surface functional groups on $\mathrm{BC}$ particles. Boehm titration depends on the reaction of basic solutions having different $\mathrm{p} K_{\mathrm{b}}$ values with functional groups having different $\mathrm{p} K_{\mathrm{a}}$ values. A weak basic $\mathrm{NaHCO}_{3}$ solution was used to neutralize strong acidic functional groups with $\mathrm{p} K_{\mathrm{a}}$ values of less than 6.37, and a $\mathrm{NaOH}$ solution was used to neutralize all acidic functional groups with $\mathrm{p} K_{\mathrm{a}}$ values of less than 15.74 (Laszlo et al., 2004). The amount of $\mathrm{NaHCO}_{3}$ solution used for titration corresponds to the amount of carboxylic groups $\left(\mathrm{p} K_{\mathrm{a}}<6.37\right.$ ), whereas the titration with $\mathrm{NaOH}$ solution quantifies total acidic functional groups. The difference between neutralization of $\mathrm{NaOH}$ and $\mathrm{NaHCO}_{3}$ was defined as phenolic and lactonic groups $\left(6.37<\mathrm{p} K_{\mathrm{a}}<15.74\right)$. A sample weight of $0.3 \mathrm{~g} \mathrm{BC}$ was suspended in $15 \mathrm{~mL} 0.1 \mathrm{~N}$ standard basic solution and shaken in a closed container for $30 \mathrm{~h}$. The slurry was filtered with a Whatman No. 42 filter paper to remove BC particles. An aliquot of $5 \mathrm{~mL}$ was transferred to a $10-\mathrm{mL} 0.1 \mathrm{~N} \mathrm{HCl}$ solution that neutralized the unreacted base and prevented further reaction between atmospheric $\mathrm{CO}_{2}$ and the bases. The solution was back-titrated with $0.1 \mathrm{~N} \mathrm{NaOH}$. The base uptake by $\mathrm{BC}$ was converted to the content of surface functional groups $\left(\right.$ mmole $\left.\mathrm{g}^{-1}\right)$. The determination of surface functional groups by the Boehm titration is affected by the presence of metal oxides or other organic matter (Boehm, 1966) and titrations were therefore only performed on $\mathrm{BC}$ particles and not on $\mathrm{BC}-$ soil mixtures.

\subsection{FT-IR}

FT-IR absorbance spectra were recorded between 400 and $4000 \mathrm{~cm}^{-1}$ with a Matteson Model 5020 FTIR Spectrometer. $\mathrm{KBr}$ pellets were prepared containing $0.3 \%$ wt of finely ground $\mathrm{BC}$ powder from both the $\mathrm{BC}$ and $\mathrm{BC}-$-soil mixtures as well as the control soil without $\mathrm{BC}$ amendment. One hundred scans were averaged with a resolution of $4 \mathrm{~cm}^{-1}$ by subtracting values obtained for pure $\mathrm{KBr}$ pellets.

\subsection{Solid-state nuclear magnetic resonance spectroscopy (NMR)}

Solid-state ${ }^{13} \mathrm{C}$ nuclear magnetic resonance (NMR) spectra were conducted at the Wiley environmental molecular sciences laboratory (EMSL) using an Infinity CMX $300-\mathrm{MHz}$ spectrometer (Varian Inc., Palo Alto, CA, USA). Variable amplitude cross-polarization (vacp) magic angle spinning (MAS) experiments were run using a $7.5 \mathrm{~mm}$ MAS HX Chemagnetics probe. The sleeves of the pencil design rotors were made from zirconia and used Kel-F drive tips and low carbon background spacers. The experiments were run using a speed of $7 \mathrm{kHz}$, the contact time was $0.5 \mathrm{~ms}$ and the delay time was $3 \mathrm{~s}$. Carbon chemical shifts were externally referenced to the methyl resonance of hexamethylbenzene at $17.36 \mathrm{ppm}$. Approximately 4000 transients were recorded for each sample.

\subsection{X-ray photoelectron spectroscopy (XPS)}

Surface analysis of the BC particles was conducted using XPS. The XPS measurements can probe a maximum sampling depth of approximately $10 \mathrm{~nm}$ and therefore provide information about surface properties. XPS measurements were conducted at the Wiley Environmental Molecular Sciences Laboratory using a physical electronics quantum 2000 scanning ESCA Microprobe (Physical Electronics $\mathrm{GmbH}$, Ismaning, Germany, a division of ULVAC PHI), which used a focused monochromatic Al Ka X-ray (1486.7 eV) source for excitation and a spherical section analyzer. The $98-\mathrm{W}, 107-\mu \mathrm{m}$ diameter X-rays had a rastered pattern over a 1.4 by $0.2 \mathrm{~mm}$ rectangle on the sample. Survey scan spectra in the $1000-0 \mathrm{eV}$ binding energy range were recorded with a pass energy of $117.4 \mathrm{eV}$. Highenergy resolution scan spectra of $\mathrm{C} 1 \mathrm{~s}$ and $\mathrm{O} 1 \mathrm{~s}$ were recorded in $0.2 \mathrm{eV}$ steps with a pass energy of $46.95 \mathrm{eV}$. Low energy electrons and Ar ions were 
conducted for specimen neutralization in each measurement.

Unaltered BC particles were measured in comparison with finely-ground $\mathrm{BC}$ powder. The spectra from the $\mathrm{BC}$ particles were assumed to represent the properties of the real surface of the particles, whereas the spectra of the finely-ground powder were assumed to be representative of the bulk BC sample, including both exterior and interior properties. Samples were mounted on to stainless steal sample holders and were gently pressed on to adhesive tape using a propanol-washed spatula. The samples were verified to cover the entire tape by stereomicroscopy.

A non-linear least squares curve fitting program (XPSPEAK Version 4.1 software, programmed by R. Kwok, Chinese University of Hong Kong) with a Gaussian-Lorentzian mix function and Shirley background subtraction was used to deconvolute the XPS spectra. The C1s binding energy of graphitic or aromatic $\mathrm{C}$ and hydrocarbon was assigned at $284.6 \mathrm{eV}$. The shifts of the $\mathrm{C} 1 \mathrm{~s}$ binding energy were defined for $1.6 \mathrm{eV}$ as $\mathrm{C}-\mathrm{O}$, for $3.0 \mathrm{eV}$ as $\mathrm{C}=\mathrm{O}$, and for $4.5 \mathrm{eV}$ as $\mathrm{COO}$ (Proctor and Sherwood, 1982). The deconvolution of O1s was done by separating $\mathrm{O}$ with a double $\mathrm{C}$ bond $(\mathrm{O}=\mathrm{C})$ with a binding energy at $531.3 \mathrm{eV}$, and $\mathrm{O}$ with a single $\mathrm{C}$ bond (such as hydroxyl or ester in $\mathrm{O}-\mathrm{C}$ or $\mathrm{O}-\mathrm{H}$ bonds) with a binding energy at $533.1 \mathrm{eV}$. The deconvolution of $\mathrm{C} 1 \mathrm{~s}$ and $\mathrm{O} 1 \mathrm{~s}$ spectra in $\mathrm{BC}$ particles or finely ground powder was set to the same FWTH values and Gaussian-Lorentzian ratios.

\subsection{Statistical analysis}

Data were analyzed using SAS Version 8 (SAS Institute Inc., Cary, NC, USA). Separation of the means was performed using Duncan differences calculated with the ANOVA procedure.

\section{Results}

\subsection{Chemical properties}

The $\mathrm{pH}$ values of the $\mathrm{BC}$ before incubation were 5.3 and 4.0 in water and $\mathrm{KCl}$ solution, respectively, exchangeable acidity was $52 \mathrm{mmole} \mathrm{kg}^{-1}$ and the potential CEC (P-CEC) was 140 mmole $\mathrm{kg}^{-1}$ (Table 1). These values for P-CEC were significantly higher

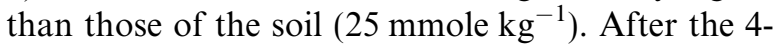
month incubation, P-CEC of BC significantly increased with all additions at both temperatures. Consequently, P-CEC of soil significantly increased by $90 \%$ after addition of BC (Table 1 ). The presence of microbial activity did not further increase PCEC, while additions of manure led to an additional $64 \%$ and $39 \%$ increase compared to the $\mathrm{BC}$ and $\mathrm{BC}-$ soil mixtures, respectively, without further applications. Nutrient addition $(+F$ in Table 1$)$ did not improve P-CEC in any combinations. The largest increase in P-CEC was observed when $\mathrm{BC}$ and $\mathrm{BC}$-soil mixtures were incubated at $70^{\circ} \mathrm{C}$ (by $538 \%$ and $285 \%$, respectively), while P-CEC of the soil alone did not increase.

The $\mathrm{pH}$ in water was greater in $\mathrm{BC}$ than in soil, while the $\mathrm{pH}$ in $\mathrm{KCl}$ was lower in $\mathrm{BC}$ than in soil (Table 1). In contrast to $\mathrm{P}-\mathrm{CEC}$, the $\mathrm{pH}$ of $\mathrm{BC}$ particles slightly decreased after the incubation at $30{ }^{\circ} \mathrm{C}$. Manure addition significantly increased $\mathrm{pH}$, whereas nutrient addition did not induce any change in $\mathrm{pH}$. Incubation at $70^{\circ} \mathrm{C}$ of $\mathrm{BC}$ and $\mathrm{BC}-$ soil mixtures significantly decreased the $\mathrm{pH}$ and $\mathrm{pH}$ in $\mathrm{KCl}$ of $\mathrm{BC}$ alone dropped to a very low value of 2.3 .

The changes in exchangeable acidity reflected the trends seen for the $\mathrm{pH}$ in $\mathrm{BC}$, but the absolute values were much higher in $\mathrm{BC}$ compared to soil (52 versus $3.6 \mathrm{mmole} \mathrm{kg}^{-1}$, respectively). In $\mathrm{BC}$-soil mixtures, the changes in acidity were more pronounced than for $\mathrm{BC}$ alone. Both exchangeable acidity and $\mathrm{Al}$ of soil alone doubled after incubation at $70^{\circ} \mathrm{C}$, whereas exchangeable $\mathrm{Al}$ was entirely absent from $\mathrm{BC}$. When $\mathrm{BC}$ was incubated with soil at $70{ }^{\circ} \mathrm{C}$, the exchangeable $\mathrm{Al}$ significantly increased by $75 \%$ over unamended soil. Manure addition did not significantly decrease exchangeable $\mathrm{Al}$ in soil-BC mixtures incubated at $70^{\circ} \mathrm{C}$, whereas exchangeable $\mathrm{Al}$ was absent when the mixtures were incubated at $30^{\circ} \mathrm{C}$.

\subsection{Elemental and isotopic composition}

Incubation at $30{ }^{\circ} \mathrm{C}$ both with and without the presence of microorganisms did not affect $\mathrm{C}$ and $\mathrm{O}$ contents of $\mathrm{BC}$ particles (Table 2). Manure addition decreased the $\mathrm{C}$ and increased the $\mathrm{O}$ concentrations. The $\mathrm{BC}$ incubated at $70{ }^{\circ} \mathrm{C}$ had the lowest $\mathrm{C}$ and the highest $\mathrm{O}$ content among all treatments. $\mathrm{The} \mathrm{H} / \mathrm{C}$ atomic ratio did not show much difference, while the $\mathrm{O} / \mathrm{C}$ atomic ratio increased through incubation at $70{ }^{\circ} \mathrm{C}$ from 0.19 to 0.29 .

The incubation did not change the $\delta{ }^{13} \mathrm{C}$ value, except for the $\mathrm{BC}$ to which manure was added. However, incubation led to an increase in the $\delta \mathrm{D}$ value and a decrease in the $\delta{ }^{18} \mathrm{O}$ value. In general, 
Table 1

The chemical properties of $\mathrm{BC}$ and $\mathrm{BC}$-soil mixtures under different incubation treatments

\begin{tabular}{|c|c|c|c|c|c|}
\hline Treatment & $\mathrm{pH}$ in Water & $\mathrm{pH}$ in $1 \mathrm{~N} \mathrm{KCl}$ & Ex-acidity $\left(\right.$ mmole $\left.\mathrm{kg}^{-1}\right)$ & $\mathrm{Ex}^{-\mathrm{Al}^{\mathrm{a}}}\left(\right.$ mmole kg $\left.{ }^{-1}\right)$ & P-CEC ${ }^{\mathrm{b}}\left(\right.$ mmole $\left.\mathrm{kg}^{-1}\right)$ \\
\hline \multicolumn{6}{|l|}{ Black carbon } \\
\hline Original $\mathrm{BC}^{\mathrm{c}}$ & $5.35 \mathrm{c} \pm 0.03^{\mathrm{d}}$ & $4.00 \mathrm{c} \pm 0.02$ & $52 \mathrm{e} \pm 5$ & n.d. ${ }^{\mathrm{e}}$ & $140 \mathrm{f} \pm 10$ \\
\hline $30^{\circ} \mathrm{C} \mathrm{C}$ & $5.22 \mathrm{~cd} \pm 0.07$ & $3.70 \mathrm{~d} \pm 0.11$ & $54 \mathrm{e} \pm 3$ & n.d. & $214 \mathrm{e} \pm 14$ \\
\hline $\mathrm{C}+\mathrm{F}$ & $5.12 \mathrm{~d} \pm 0.02$ & $3.74 d \pm 0.06$ & $47 \mathrm{e} \pm 4$ & n.d. & $224 \mathrm{e} \pm 8$ \\
\hline $\mathrm{C}+\mathrm{Mic}$ & $5.21 \mathrm{~d} \pm 0.01$ & $3.78 \mathrm{~d} \pm 0.01$ & $52 \mathrm{e} \pm 1$ & n.d. & $186 \mathrm{e} \pm 10$ \\
\hline $\mathrm{C}+\mathrm{Man}$ & $6.88 \mathrm{a} \pm 0.07$ & $6.61 \mathrm{a} \pm 0.12$ & $90 \mathrm{~d} \pm 4$ & n.d. & $350 \mathrm{~d} \pm 40$ \\
\hline $\mathrm{C}+\mathrm{F}+\mathrm{Mic}$ & $5.19 \mathrm{~d} \pm 0.10$ & $3.80 \mathrm{~d} \pm 0.04$ & $50 \mathrm{e} \pm 2$ & n.d. & $206 \mathrm{e} \pm 11$ \\
\hline $\mathrm{C}+\mathrm{Mic}+\mathrm{Man}$ & $6.71 b \pm 0.11$ & $6.62 \mathrm{a} \pm 0.11$ & $90 \mathrm{~d} \pm 17$ & n.d. & $356 \mathrm{~d} \pm 24$ \\
\hline $\mathrm{C}+\mathrm{F}+\mathrm{Mic}+\mathrm{Man}$ & $6.93 \mathrm{a} \pm 0.11$ & $6.73 a \pm 0.08$ & $85 \mathrm{~d} \pm 4$ & n.d. & $383 \mathrm{~d} \pm 30$ \\
\hline $70^{\circ} \mathrm{C} \mathrm{C}$ & $3.41 \mathrm{f} \pm 0.06$ & $2.25 f \pm 0.03$ & $202 b \pm 5$ & n.d. & $893 a \pm 66$ \\
\hline $\mathrm{C}+\mathrm{F}$ & $3.46 \mathrm{f} \pm 0.05$ & $2.41 \mathrm{e} \pm 0.05$ & $170 \mathrm{c} \pm 2$ & n.d. & $759 b \pm 116$ \\
\hline $\mathrm{C}+\mathrm{Man}$ & $4.85 \mathrm{e} \pm 0.09$ & $4.34 b \pm 0.12$ & $243 a \pm 31$ & n.d. & $601 \mathrm{c} \pm 64$ \\
\hline \multicolumn{6}{|l|}{ Black carbon and soil mixtures } \\
\hline $30^{\circ} \mathrm{C}$ Soil & $4.33 \mathrm{fg} \pm 0.07$ & $4.12 \mathrm{f} \pm 0.01$ & $3.6 \mathrm{~d} \pm 0.1$ & $1.9 \mathrm{c} \pm 0.1$ & $25.0 \mathrm{e} \pm 4.2$ \\
\hline Soil $+\mathrm{C}^{\mathrm{c}}$ & $4.48 \mathrm{ef} \pm 0.04$ & $4.13 f \pm 0.01$ & $3.9 \mathrm{~d} \pm 0.3$ & $1.5 \mathrm{~cd} \pm 0.2$ & $47.4 \mathrm{~d} \pm 3.6$ \\
\hline Soil + C + F & $4.48 \mathrm{ef} \pm 0.06$ & $4.21 \mathrm{e} \pm 0.03$ & $2.9 \mathrm{de} \pm 0.8$ & $1.1 \mathrm{de} \pm 0.2$ & $46.1 \mathrm{~d} \pm 5.7$ \\
\hline Soil + C + Mic & $4.83 \mathrm{~d} \pm 0.09$ & $4.37 d \pm 0.02$ & $2.2 \mathrm{e} \pm 0.1$ & $0.7 \mathrm{e} \pm 0.1$ & $44.5 \mathrm{~d} \pm 4.4$ \\
\hline Soil + C + Man & $6.3 \mathrm{c} \pm 0.032$ & $5.59 \mathrm{c} \pm 0.08$ & $0.8 \mathrm{f} \pm 0.1$ & n.d. & $65.9 \mathrm{c} \pm 7.6$ \\
\hline Soil + C + F + Mic & $4.61 \mathrm{e} \pm 0.08$ & $4.27 \mathrm{e} \pm 0.04$ & $2.2 \mathrm{e} \pm 0.3$ & $1.1 \mathrm{de} \pm 0.4$ & $42.6 \mathrm{~d} \pm 2.7$ \\
\hline Soil + C + Mic + Man & $6.71 \mathrm{a} \pm 0.02$ & $6.15 a \pm 0.02$ & $0.6 f \pm 0.1$ & n.d. & $61.3 \mathrm{c} \pm 5.9$ \\
\hline Soil + C + F + Mic + Man & $6.50 \mathrm{~b} \pm 0.05$ & $5.85 b \pm 0.10$ & $0.5 f \pm 0.3$ & n.d. & $62.2 \mathrm{c} \pm 3.7$ \\
\hline $70^{\circ} \mathrm{C}$ Soil & $4.14 \mathrm{~h} \pm 0.01$ & $3.94 \mathrm{~g} \pm 0.02$ & $7.2 \mathrm{c} \pm 0.3$ & $4.0 \mathrm{~b} \pm 0.1$ & $22.8 \mathrm{e} \pm 1.4$ \\
\hline Soil + C & $4.17 \mathrm{~h} \pm 0.03$ & $3.68 \mathrm{~h} \pm 0.04$ & $19.1 \mathrm{a} \pm 1.8$ & $7.0 \mathrm{a} \pm 0.4$ & $87.8 \mathrm{a} \pm 11.2 \mathrm{~b}$ \\
\hline Soil + C + F & $4.17 \mathrm{hg} \pm 0.08$ & $3.58 \mathrm{i} \pm 0.07$ & $14.5 b \pm 1.8$ & $6.1 \mathrm{a} \pm 0.7$ & $92.4 \mathrm{a} \pm 5.8$ \\
\hline Soil + C + Man & $4.59 \mathrm{e} \pm 0.03$ & $4.12 \mathrm{f} \pm 0.05$ & $14.1 b \pm 0.8$ & $6.7 \mathrm{a} \pm 0.9$ & $79.8 b \pm 7.3$ \\
\hline
\end{tabular}

Values in one column inside either $\mathrm{BC}$ or $\mathrm{BC}-$-soil mixture groups followed by the same letter are not significantly different at $P<0.05$.

a Ex-Al: exchangeable aluminum.

b P-CEC: potential CEC.

c $\mathrm{BC}$ sample before incubation.

${ }^{\mathrm{d}}$ Means \pm standard deviation.

e n.d.: not detected.

the changes were more pronounced with a higher incubation temperature and were found to be less for $\delta \mathrm{D}$ than for $\delta{ }^{18} \mathrm{O}$. Microbial activity did not change the $\mathrm{H}$ and $\mathrm{O}$ stable isotopic composition.

\subsection{Boehm titration}

Boehm titration showed that incubation of BC at $30{ }^{\circ} \mathrm{C}$ did not significantly change surface functional groups compared to original BC, except for the carboxylic functional groups when incubated with microbial activity (C30 mic). The incubation at $70{ }^{\circ} \mathrm{C}$ significantly increased acidic functional groups. The amount of carboxylic groups increased to a greater extent than phenolic and lactonic groups as a proportion of the amount in the original BC.

\subsection{FT-IR analysis}

The most prominent absorptions for BC included $\mathrm{O}-\mathrm{H}$ bonds at $3400 \mathrm{~cm}^{-1}$ (Fig. 1; Table 4), aliphatic

Table 2

Elemental composition and stable isotope values of $\mathrm{BC}$ under different incubation treatments and the atomic $\mathrm{H} / \mathrm{C}$ and $\mathrm{O} / \mathrm{C}$ ratio based on elemental analysis (means \pm standard deviation or pooled samples from $N=4$ )

\begin{tabular}{|c|c|c|c|c|c|c|c|c|}
\hline & $\mathrm{C}(\%)$ & $\delta^{13} \mathrm{C}(\%)$ & $\mathrm{H}(\%)$ & $\delta \mathrm{D}(\%)$ & $\mathrm{O}(\%)$ & $\delta^{18} \mathrm{O}(\%)$ & $\mathrm{H} / \mathrm{C}$ & $\mathrm{O} / \mathrm{C}$ \\
\hline Original $\mathrm{BC}$ & $74.3 \mathrm{a} \pm 0.2$ & $-24.9 b \pm 0.0$ & 1.9 & -110.7 & 19.2 & 20.3 & 0.30 & 0.19 \\
\hline $\mathrm{C} 30$ & $74.1 \mathrm{a} \pm 1.5$ & $-24.9 b \pm 0.0$ & 2.1 & -93.6 & 19.9 & 18.5 & 0.33 & 0.20 \\
\hline $\mathrm{C} 30 \mathrm{mic}$ & $75.7 \mathrm{a} \pm 1.4$ & $-25.0 b \pm 0.0$ & 2.0 & -89.3 & 19.3 & 18.5 & 0.32 & 0.19 \\
\hline C30 man & $65.1 \mathrm{c} \pm 1.2$ & $-21.9 \mathrm{a} \pm 0.1$ & 2.5 & -84.7 & 25.2 & 18.1 & 0.47 & 0.29 \\
\hline $\mathrm{C} 70$ & $67.7 b \pm 1.3$ & $-24.9 b \pm 0.1$ & 1.9 & -82.0 & 26.3 & 12.6 & 0.33 & 0.29 \\
\hline $\mathrm{C} 70 \mathrm{~F}$ & $70.8 \mathrm{~b} \pm 1.8$ & $-24.9 b \pm 0.0$ & 1.7 & -71.4 & 23.5 & 14.1 & 0.28 & 0.25 \\
\hline
\end{tabular}


$\mathrm{C}-\mathrm{H}$ bonds at $2750-2950 \mathrm{~cm}^{-1}$, carboxylic $(\mathrm{COOH})$ bonds at $1700 \mathrm{~cm}^{-1}$, aromatic bonds $(\mathrm{C}=\mathrm{C})$ at $1600 \mathrm{~cm}^{-1}$ and $\mathrm{C}-\mathrm{O}$ bonds at $1260 \mathrm{~cm}^{-1}$. Minor bands could also be noticed for some spectra, such as polysaccharide $\mathrm{C}-\mathrm{O}$ bonds at $1035 \mathrm{~cm}^{-1}$ (Fig. 1a) when manure was applied (C30 man). In the $\mathrm{BC}$ isolated from $\mathrm{BC}-$ soil mixtures or the soil samples (Fig. 1b), additional $\mathrm{O}-\mathrm{H}$ stretching of kaolinite at $3700-3800 \mathrm{~cm}^{-1}$ and $\mathrm{Si}-\mathrm{O}$ vibrations at $1040 \mathrm{~cm}^{-1}$ could be observed.

None of the BC incubated at $30^{\circ} \mathrm{C}(\mathrm{C} 30$, $\mathrm{C} 30 \mathrm{mic}, \mathrm{C} 30 \mathrm{man}$ ) was different from the original $\mathrm{BC}$ (Original $\mathrm{BC}$ ) with respect to spectral intensities of $\mathrm{O}-\mathrm{H}$ bonds, carboxylic bonds, and $\mathrm{C}=\mathrm{C}$ bonds (Fig. 1). Microbial inoculation and manure application additionally showed greater intensity for aliphatic $\mathrm{C}-\mathrm{H}$ bonds and a wider $\mathrm{C}=\mathrm{C}$ peak. The latter is likely a result of the contribution of other aromatic structures with greater asymmetry than for BC. Manure addition also led to a distinct poly- saccharide $\mathrm{C}-\mathrm{O}$ absorbance at $1035 \mathrm{~cm}^{-1}$. The most pronounced changes were observed after incubation of $\mathrm{BC}$ at $70^{\circ} \mathrm{C}$, which led to greater intensity for carboxylic bonds $\left(1700 \mathrm{~cm}^{-1}\right)$, aromatic $\mathrm{C}-\mathrm{O}$ bonds $\left(1260 \mathrm{~cm}^{-1}\right)$, and a slightly lower intensity for aliphatic $\mathrm{C}-\mathrm{H}$ bonds $\left(2750-2950 \mathrm{~cm}^{-1}\right)$ and slightly increasing aromatic $\mathrm{C}-\mathrm{H}\left(3050 \mathrm{~cm}^{-1}\right)$. The $\mathrm{BC}$ isolated from the $\mathrm{BC}$-soil mixture at $70{ }^{\circ} \mathrm{C}$ (Fig. 1b) showed similar trends in shifts compared to the $\mathrm{BC}$ incubated alone. However, the magnitude of carboxylation was greater when $\mathrm{BC}$ was incubated alone and not together with soil as indicated by the $2-10 \%$ greater ratio of peak heights for carboxylic-to-aromatic $\mathrm{C}$ absorptions (1700 versus $\left.1600 \mathrm{~cm}^{-1}\right)$.

\subsection{NMR spectroscopy}

Carbon forms in the original $\mathrm{BC}$ were dominated by aryl and O-aryl $\mathrm{C}$ at $90-160 \mathrm{ppm}$, with lower
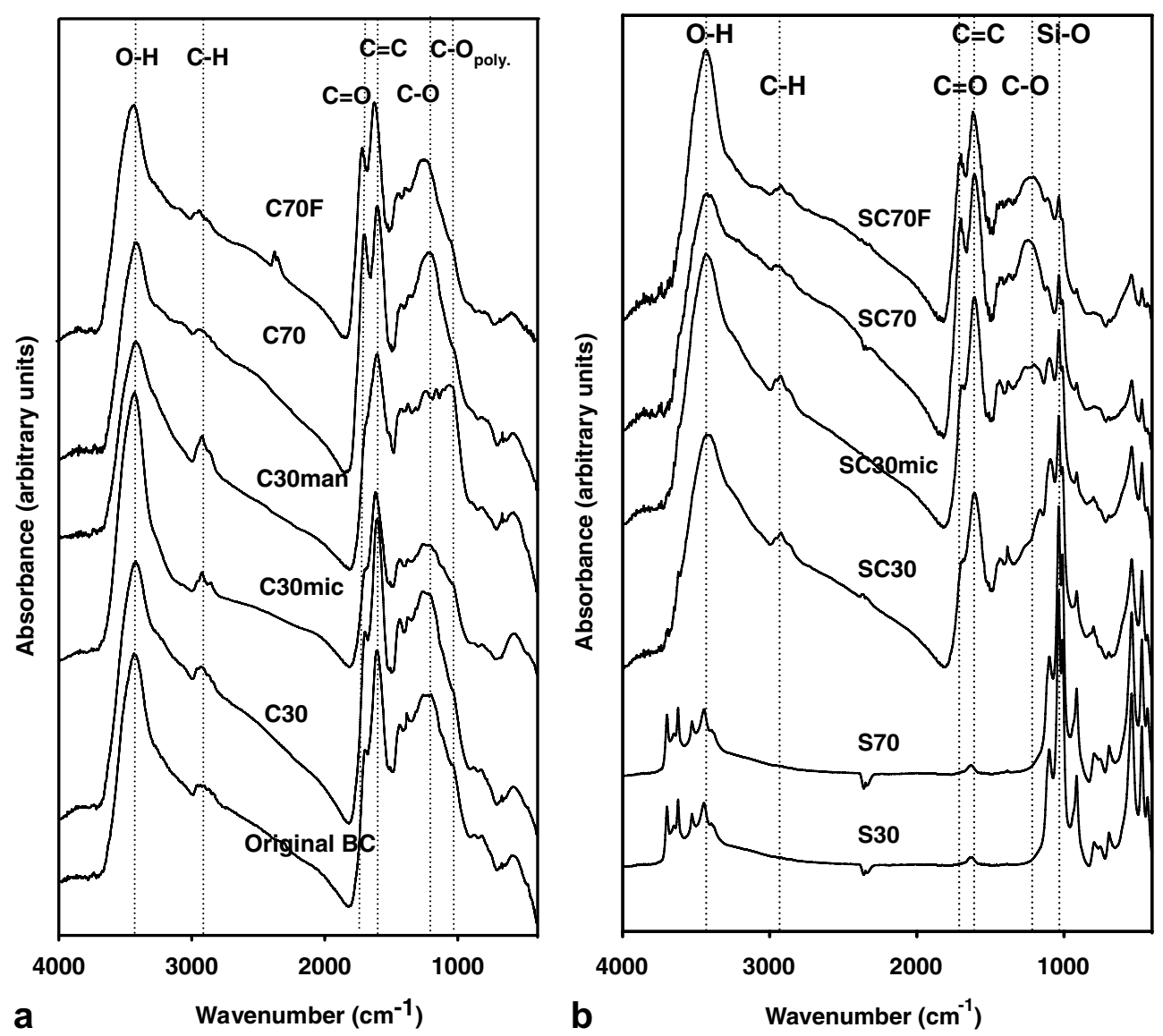

Fig. 1. FT-IR spectra of BC (a) and BC-soil mixtures (b) incubated at 30 and $70{ }^{\circ} \mathrm{C}$, with (mic) and without microbial activity, and 
Table 3

Surface functional groups determined by Boehm titration

\begin{tabular}{|c|c|c|c|}
\hline & Carboxylic groups (mmole $\mathrm{g}^{-1}$ ) & Phenolic and Lactonic groups (mmole $\mathrm{g}^{-1}$ ) & Total acidic functional groups ( $\mathrm{mmole}^{-1}$ ) \\
\hline Original $\mathrm{BC}$ & $0.16 \mathrm{~d} \pm 0.02$ & $1.66 \mathrm{~b} \pm 0.19$ & $1.82 b \pm 0.19$ \\
\hline $\mathrm{C} 30$ & $0.21 \mathrm{~d} \pm 0.02$ & $1.69 b \pm 0.18$ & $1.90 \mathrm{~b} \pm 0.19$ \\
\hline $\mathrm{C} 30 \mathrm{~F}$ & $0.29 \mathrm{~cd} \pm 0.03$ & $1.58 \mathrm{~b} \pm 0.07$ & $1.87 \mathrm{~b} \pm 0.07$ \\
\hline $\mathrm{C} 30 \mathrm{mic}$ & $0.34 \mathrm{c} \pm 0.08$ & $1.71 b \pm 0.26$ & $2.06 \mathrm{~b} \pm 0.19$ \\
\hline $\mathrm{C} 70$ & $0.89 \mathrm{a} \pm 0.10$ & $2.70 \mathrm{a} \pm 0.34$ & $3.59 \mathrm{a} \pm 0.29$ \\
\hline $\mathrm{C} 70 \mathrm{~F}$ & $0.73 b \pm 0.10$ & $2.83 \mathrm{a} \pm 0.10$ & $3.56 \mathrm{a} \pm 0.03$ \\
\hline
\end{tabular}

Values in one column followed by the same letter are not significantly different at $P<0.05$ (means \pm standard deviation).

Table 4

Major band assignments for FT-IR spectra of BC (van der Marel and Beutelspacher, 1976; Morterra et al., 1984; Guo and Bustin, 1998)

\begin{tabular}{ll}
\hline Wavenumber $\left(\mathrm{cm}^{-1}\right)$ & Band assignments \\
\hline $3700-3800$ & Stretching of $\mathrm{OH}$ vibration of kaolinite \\
3400 & Stretching of OH vibration \\
3050 & Stretching of aromatic $\mathrm{C}-\mathrm{H}$ \\
$2750-2950$ & Stretching vibrations of aliphatic $\mathrm{C}-\mathrm{H}$. \\
$1690-1710$ & Stretching mainly of carboxyl-C and traces of ketones and esters $\mathrm{C}=\mathrm{O}$ \\
$1595-1630$ & Stretching of aromatic $\mathrm{C}=\mathrm{C}$ \\
$1430-1440$ & Deformation of $\mathrm{CH}_{2}$ and $\mathrm{CH}$ bending \\
$1370-1395$ & Deformation of aliphatic $\mathrm{C}-\mathrm{H}$ (some $\mathrm{C}-\mathrm{O}$ stretching of phenolic $\mathrm{OH})$ \\
$1255-1265$ & Stretching of aromatic $\mathrm{C}-\mathrm{O}$ and phenolic $\mathrm{OH}$ \\
1040 & Si-O vibrations \\
1035 & Stretching of polysaccharide $\mathrm{C}-\mathrm{O}$ \\
\hline
\end{tabular}

intensities of alkyl $\mathrm{C}$ at $0-50 \mathrm{ppm}$ and only traces of carboxylic or ketone $\mathrm{C}$ at 160-200 ppm (Fig. 2). The decrease in alkyl $\mathrm{C}$ was the most prominent change during the incubation process. The amount of carboxylic $\mathrm{C}$ did not show a clear increase during incubation.

\subsection{XPS analysis}

The XPS wide-scan spectra showed the presence of two distinct peaks in $\mathrm{C}(\mathrm{C} 1 \mathrm{~s})$ at $284.6 \mathrm{eV}$ and $\mathrm{O}$ $(\mathrm{O} 1 \mathrm{~s})$ at $533 \mathrm{eV}$ and two small peaks in $\mathrm{N}(\mathrm{N} 1 \mathrm{~s})$ at $400 \mathrm{eV}$ and $\mathrm{Ca}(\mathrm{Ca} 2 \mathrm{p})$ at $350 \mathrm{eV}$ (high resolution spectra for $\mathrm{C}$ and $\mathrm{O}$ in Fig. 3; for $\mathrm{N}$ and $\mathrm{Ca}$ not shown). The bulk properties of $\mathrm{BC}$ (BC powder, Table 5) showed the same trend in elemental content of $\mathrm{C}$ and $\mathrm{O}$ as the results obtained from dry combustion (Table 2): a negligible increase in $\mathrm{O}$ and no decrease in $\mathrm{C}$ during incubation at $30^{\circ} \mathrm{C}$. However, incubation at $70^{\circ} \mathrm{C}$ led to a pronounced increase in $\mathrm{O}$ and a correspondingly lower $\mathrm{C}$ concentration. The $\mathrm{O} / \mathrm{C}$ ratio of original $\mathrm{BC}$ of the interior (being the bulk of what was assessed through analyzing $\mathrm{BC}$ powder, Table 5) was similar to the $\mathrm{O} / \mathrm{C}$ ratio of the surface ( $\mathrm{BC}$ particles, Table 5). During the incubation at $30^{\circ} \mathrm{C}$, however, the $\mathrm{O} / \mathrm{C}$ ratio of $\mathrm{BC}$ surfaces increased by more than $20 \%$ of the value of the original $\mathrm{BC}$. This was not

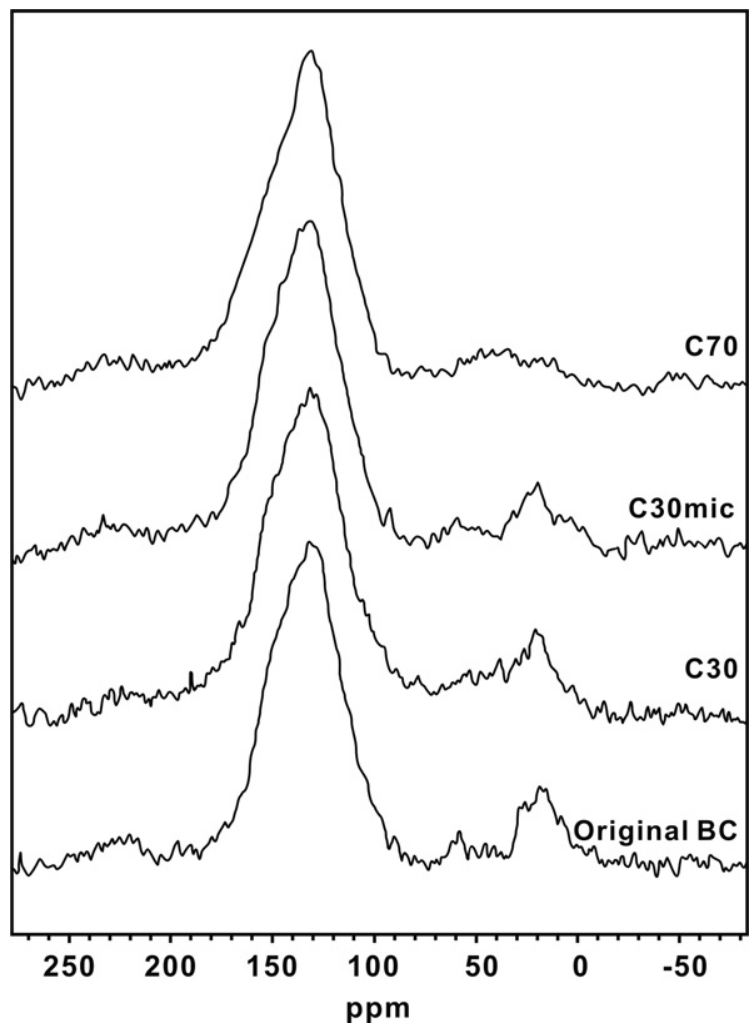

Fig. 2. NMR spectroscopy of $\mathrm{BC}$ incubated at 30 and $70{ }^{\circ} \mathrm{C}$, with (mic) and without microbial activity in comparison to original BC. 
observed for the bulk properties (BC powder, Table 5). If a temperature of $70{ }^{\circ} \mathrm{C}$ was used, the $\mathrm{O} / \mathrm{C}$ ratios were identical both for the surface and the interior.

The spectra of high resolution XPS of C1s and $\mathrm{O} 1 \mathrm{~s}$ were used to quantify the $\mathrm{C}$ and $\mathrm{O}$ forms on surfaces (BC particles) and in the interior (BC powder) (Fig. 3, spectra were normalized on the basis of intensity). Incubation of $\mathrm{BC}$ at $70^{\circ} \mathrm{C}$ yielded the most contrasting spectra compared to the other treatments, leading to higher intensity at $\mathrm{C}$ 1s $289.1 \mathrm{eV}$ and O1s $531.3 \mathrm{eV}$. Similar to the total elemental data obtained from XPS (Table 5), the highresolution XPS did not show a difference in bulk properties of $\mathrm{BC}$ after incubation at $30^{\circ} \mathrm{C}$ (Fig. 3; Table 6). $\mathrm{BC}$ incubated at $30^{\circ} \mathrm{C}$ only enhanced the formation of oxidized $\mathrm{C}$ groups on surfaces. However, the incubation at $70{ }^{\circ} \mathrm{C}$ resulted in significant oxidation of both surfaces and bulk $\mathrm{BC}$ mainly through the formation of carboxylic C (BC particles, Table 6). As noted for all the other experiments in this study, the presence of microbial activity did also not change the degree of surface oxidation.
Table 5

Atomic elemental contents of $\mathrm{C}, \mathrm{N}, \mathrm{O}$, and $\mathrm{Ca}$ and atomic $\mathrm{O} / \mathrm{C}$ ratios measured from XPS widescan spectra of BC particles and finely ground powder (pooled samples from $N=4$ )

\begin{tabular}{llllll}
\hline & $\mathrm{C}(\%)$ & $\mathrm{N}(\%)$ & $\mathrm{O}(\%)$ & $\mathrm{Ca}(\%)$ & $\mathrm{O} / \mathrm{C}(\%)$ \\
\hline BC particles & & & & & \\
Original BC & 82.9 & 0.7 & 16.3 & 0.1 & 0.20 \\
C30 & 79.3 & 1.0 & 19.8 & 0.2 & 0.25 \\
C30 mic & 79.6 & 0.6 & 19.5 & 0.3 & 0.24 \\
C70 & 78.2 & 0.5 & 21.2 & 0.2 & 0.27 \\
BC powder & & & & & \\
Original BC & 82.1 & 0.3 & 17.6 & nil & 0.21 \\
C30 & 81.1 & 0.5 & 18.4 & nil & 0.23 \\
C30 mic & 82.2 & 0.4 & 17.4 & nil & 0.21 \\
C70 & 78.3 & 0.3 & 21.4 & nil & 0.27 \\
\hline
\end{tabular}

\section{Discussion}

\subsection{Biotic and abiotic oxidation of $B C$}

Abiotic oxidation was found to be more important for the creation of negative surface charge and CEC than biotic oxidation, which is in contrast to our initial hypothesis. The presence of microbial
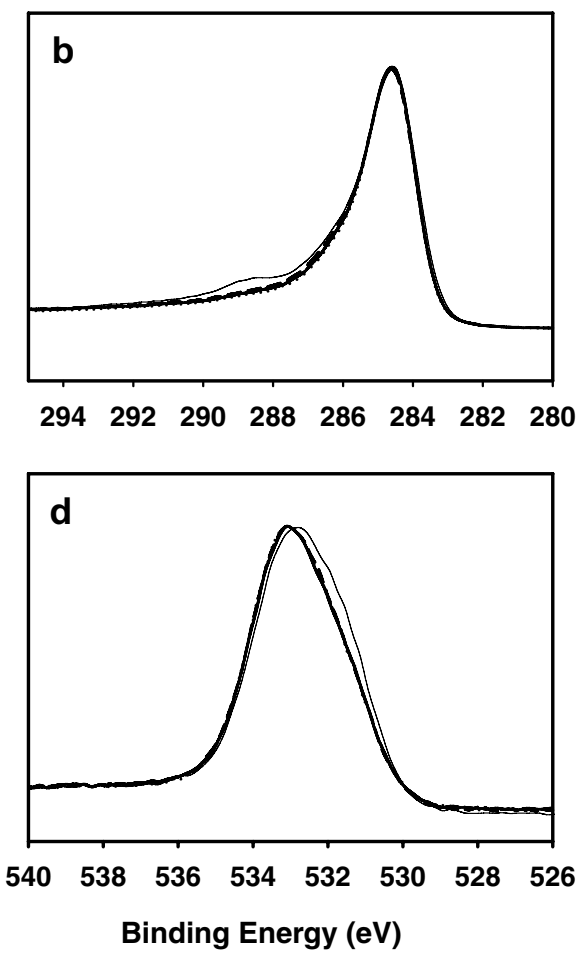

Fig. 3. XPS spectra of $\mathrm{BC}$ incubated at 30 and $70^{\circ} \mathrm{C}$, with (mic) and without microbial activity in comparison to original $\mathrm{BC}$; $\mathrm{C} 1 \mathrm{~s}$ of $\mathrm{BC}$ particles (a) and powder (b) as well as O1s of BC particles (c) and powder (d). 
Table 6

Chemical composition of carbon $(\mathrm{Cl})$ and oxygen $(\mathrm{O} 1 \mathrm{~s})$ from high-energy resolution XPS spectra of BC particles and finely ground powder

\begin{tabular}{|c|c|c|c|c|c|c|}
\hline & \multicolumn{4}{|l|}{ C1s composition $(\%)$} & \multicolumn{2}{|c|}{ O1s composition $(\%)$} \\
\hline & $\mathrm{C}-\mathrm{C}, \mathrm{C}=\mathrm{C}$, or $\mathrm{C}-\mathrm{H}$ & $\mathrm{C}-\mathrm{O}$ & $\mathrm{C}=\mathrm{O}$ & $\mathrm{COO}$ & $\mathrm{O}=\mathrm{C}$ & $\mathrm{OH}-\mathrm{C}$ or $\mathrm{C}-\mathrm{O}-\mathrm{C}$ \\
\hline \multicolumn{7}{|l|}{$B C$ particles } \\
\hline Original $\mathrm{BC}$ & 73.5 & 15.2 & 4.4 & 6.9 & 22.6 & 77.4 \\
\hline $\mathrm{C} 30$ & 68.8 & 16.0 & 6.3 & 8.9 & 24.7 & 75.2 \\
\hline $\mathrm{C} 30 \mathrm{C}$ mic & 68.7 & 16.9 & 6.0 & 8.4 & 23.7 & 76.3 \\
\hline $\mathrm{C} 70$ & 65.9 & 16.3 & 5.2 & 12.6 & 26.7 & 73.3 \\
\hline \multicolumn{7}{|l|}{$B C$ powder } \\
\hline Original $\mathrm{BC}$ & 72.7 & 15.2 & 4.8 & 7.3 & 18.4 & 81.6 \\
\hline $\mathrm{C} 30$ & 71.4 & 15.2 & 5.2 & 8.2 & 17.2 & 82.8 \\
\hline $\mathrm{C} 30 \mathrm{mic}$ & 72.8 & 15.2 & 4.6 & 7.4 & 18.0 & 82.0 \\
\hline $\mathrm{C} 70$ & 67.4 & 14.7 & 5.6 & 12.3 & 25.8 & 74.2 \\
\hline
\end{tabular}

The binding energy of $\mathrm{C} 1 \mathrm{~s}$ at $284.6 \mathrm{eV}$ was assigned to $\mathrm{C}-\mathrm{C}, \mathrm{C}=\mathrm{C}$, and $\mathrm{C}-\mathrm{H}$, at $286.2 \mathrm{eV}$ to $\mathrm{C}-\mathrm{O}$, at $287.6 \mathrm{eV}$ to $\mathrm{C}=\mathrm{O}$, and at $289.1 \mathrm{eV}$ to COO. The binding energy of $\mathrm{O} 1 \mathrm{~s}$ at $531.3 \mathrm{eV}$ was assigned to $\mathrm{O}=\mathrm{C}$ and at $533.1 \mathrm{eV}$ to $\mathrm{O}-\mathrm{C}$.

activity had no significant effects on oxidation of $\mathrm{BC}$ during the 120 day incubation period, although other studies have found significant biotic oxidation of coal or graphitic BC (Shneour, 1966; Willmann and Fakoussa, 1997; Machnikowska et al., 2002). It should be noted that the $\mathrm{BC}$ was washed before incubation to remove soluble salts and it is possible that most tar dissolved organic $\mathrm{C}$ was leached out during the cleaning process. However, the presence of microorganisms did also not increase P-CEC when labile $\mathrm{C}$ was added in the form of manure, suggesting that the lack of easily decomposable $\mathrm{C}$ or nutrients did not limit oxidation of BC. It cannot be excluded that the ability of other microbial populations could have been greater for decomposing the $\mathrm{BC}$, since specialized microorganisms have been shown be effective in decomposing BC (Fakoussa and Hofrichter, 1999; Machnikowska et al., 2002).

Abiotic oxidation at high temperature may, to a certain extent, happen by chemisorption of $\mathrm{O}$ rather than by oxidation of reduced $\mathrm{C}$ forms (Morterra and Low, 1982), since $\delta{ }^{18} \mathrm{O}$ values decreased to a much larger extent than $\delta \mathrm{D}$ values. However, the significant increase in negative surface charge and the identification of carboxylic $\mathrm{C}$ with XPS and Boehm titration suggest that a large proportion of the oxygenation was actually oxidation of C. The oxidation of $\mathrm{BC}$ may be largely initiated by chemisorption of $\mathrm{O}$ at unsaturated ring sites and lead to a subsequent formation of carboxylic groups (Puri and Sharma, 1968). These reactions or aging processes of $\mathrm{BC}$ have been found to accelerate at higher temperature (Rideal and Wright, 1925; Bradbury and Shafizadeh, 1980; Teng and Hsieh, 1999; Chughtai et al., 2003), indicating that the reaction between soot and ozone increased three times with an increase in temperature from -35 to $+23{ }^{\circ} \mathrm{C}$. In addition to oxidation of the $\mathrm{BC}$ particles themselves, adsorption of non-BC may also increase the number of oxidized groups on BC surfaces that can create CEC (Lehmann et al., 2005). This may be the case with manure addition, as the P-CEC of $\mathrm{BC}$ particles (Table 1) increased much more by incubation with than without manure additions. A pronounced increase in the adsorption of ammonium was also observed by coating BC particles with manure extract (Lehmann et al., 2002). A similar process may be observable in soil even without manure addition, as the P-CEC increased comparatively more in the BCsoil mixture (Table 1) than when incubated alone (Table 1), considering that the $\mathrm{BC}$-soil mixture only contained about $4 \%$ BC. This is in contrast to the finding from FT-IR analysis showing that oxidation of $\mathrm{BC}$ was lower for soil mixtures than when incubated alone. A possible explanation may be the difference between the analysis achieved by FT-IR that captures oxidation of the entire particle in comparison to determining CEC which only captures surface properties.

\subsection{Surface oxidation of $B C$}

Oxidation of BC was initiated on the surface of particles and analysis of the oxidation of entire particles completely masked this important process. The difference between the XPS analysis of BC particles and powder exemplifies the surface-oriented nature of initial BC oxidation. The XPS analysis of particles only captures the surface properties of 
the $\mathrm{BC}$ due to the low penetration depth of the Xray to about $10 \mathrm{~nm}$, whereas the same XPS analysis of ground particles quantifies their bulk properties. At higher temperature, the interior of $\mathrm{BC}$ particles was also oxidized, as demonstrated by FT-IR and XPS analyses. NMR spectra did not show much change in O-aryl or carboxylic $\mathrm{C}$ even at a high temperature. The lack of a clear increase in acid functional groups using Boehm titration in comparison to the significant increase in $\mathrm{P}-\mathrm{CEC}$ and $\mathrm{pH}$ values may be explained by the lower contact time during the measurements of $\mathrm{CEC}$ and $\mathrm{pH}$, which may therefore have preferentially captured surface properties.

Abiotic oxidative processes appeared to at first cause oxidation of BC surfaces. Longer exposure in soil may then gradually lead to an oxidation of the interior of BC particles. The oxidation of BC surfaces progressed from phenolic groups to a proportionally very large increase in carboxylic groups (Table 3); therefore, surface oxidation continued to increase with time. However, Lehmann et al. (2005) still observed the greatest oxidation of $\mathrm{BC}$ particles close to the surface even of $\mathrm{BC}$ with several hundred years of exposure in soil using near-edge X-ray spectroscopy.

The concentrations of carboxylic functional groups determined by Boehm titration (Table 3) were similar to the values of the P-CEC (Table 1) and it is possible that the adsorption of base cations is mainly controlled by the negative charge of carboxylic groups in BC. Pittman et al. (1999) reported similar observations using $\mathrm{Ag}$ ion adsorption on activated $\mathrm{C}$ and they suggested that carboxyl and phenolic groups (at $\mathrm{pH}$ 10) were the main adsorption sites.

\subsection{Environmental significance}

These results have significance for the stability of BC in soil as well as the effects of BC on soil fertility. Firstly, the disappearance of the aliphatic C observed using NMR and FT-IR, especially for BC samples incubated at $70^{\circ} \mathrm{C}$, indicates that aliphatic $\mathrm{C}$ compounds are more labile than aromatic C. Mawhinney and Yates (2001) also observed decomposition of aliphatic $\mathrm{C}$ in BC by ozone. Sergides et al. (1987) proposed an oxidation model of soot particles by ozone and indicated that stripping of aliphatic chains is the first stage of ozonation. The oxidation catalyst for soot also showed a removal of the aliphatic species from particles, and not from their graphitic part (Albers et al., 2000). This process was also observed for microbial oxidation (Willmann and Fakoussa, 1997), which was not observed in our study. Therefore, it is likely that the aliphatic $\mathrm{C}$ in our experiment was abiotically oxidized to $\mathrm{CO}_{2}$, as suggested by other studies (Sergides et al., 1987; Cody and Alexander, 2005).

Secondly, the increasing acidic functional groups could increase the hydrophilicity of $\mathrm{BC}$ and enhance further physical, chemical, and biological weathering, such as breaking and reducing its particle size, leaching to deeper soil horizons, and dissolution or export from the soil profile (Bird et al., 1999). It is also possible that microbial oxidation would be facilitated by this initially significant abiotic oxidation due to the increase in hydrophilicity. For a long-term perspective on BC stability, a significant oxidation by microbes can therefore not be excluded.

The surface oxidation also increased CEC, which typically enhances soil fertility through greater nutrient availability as nutrients are retained in the soil against leaching. Sombroek et al. (1993) and Glaser et al. (2001) hypothesized that oxidation of $\mathrm{BC}$ leads to a high CEC being responsible for the high soil fertility found in $\mathrm{BC}$-rich soils. The surprisingly rapid formation of CEC after only 4 months of incubation, even without microbial activity, may be important for the utilization of $\mathrm{BC}$ as a soil amendment for improving the fertility of highly weathered soils (Lehmann and Rondon, 2006).

At the same time as CEC increased, the $\mathrm{pH}$ decreased and $\mathrm{Al}$ saturation increased, which is a result of the oxidation and production of acidic functional groups. The magnitude of this change in soil $\mathrm{pH}$ by $\mathrm{BC}$ may largely depend on the amount of base cations contained in the $\mathrm{BC}$, which can vary significantly (Tryon, 1948), as well as the production temperature of BC (Mattson and Mark, 1971). Although our data showed that soil fertility may be negatively affected by $\mathrm{BC}$ oxidation through a $\mathrm{pH}$ decrease or an increase in exchangeable $\mathrm{Al}$, the net effect of $\mathrm{BC}$ oxidation on $\mathrm{pH}$ in soil may be different owing to the interaction with other organic and mineral soil materials, such as with ash or other base cations present in soil. In addition to an increase in adsorption through formation of CEC, a change of adsorption ability of both hydrophobic and hydrophilic organic pollutants through the described aging processes of $\mathrm{BC}$ could also be expected (Yang and Sheng, 2003) and warrants further research. 


\section{Conclusions}

Abiotic processes were more important than biotic processes for the initial oxidation of fresh BC. This significant and rapid oxidation may have important implications for the stability of BC since further microbial decomposition may be less constrained by the recalcitrance of aromatic ring structures typical of BC. At the same time, cation retention was significantly enhanced, which would improve soil fertility. This oxidation is sufficiently rapid to make an application of fresh $\mathrm{BC}$ to soil feasible in order to enhance crop productivity and decrease potential off-site pollution in agricultural landscapes. Longer term laboratory and field studies are needed to characterize and quantify further oxidation of $\mathrm{BC}$ to answer the question whether microbial decomposition of $\mathrm{BC}$ is facilitated by the initial abiotic oxidation.

\section{Acknowledgements}

The incubation experiments were conducted by Jackie Greenwood, Lauren Taylor and Pedro Medrano. The NMR and XPS analyses were performed in the Environmental Molecular Sciences Laboratory, a national scientific user facility sponsored by the Department of Energy's Office of Biological and Environmental Research and located at Pacific Northwest National Laboratory. The micro pH meter was provided by Bruno Xavier and Dr. James Alexanda. We are also very grateful for financial support by the Ministry of Education in Taiwan and the Kieckhefer Adirondack Fellowship of Cornell University to C.-H.C.

\section{Associate Editor-G.D. Abbott}

\section{References}

Adams, L.B., Hall, C.R., Holmes, R.J., Newton, R.A., 1988. An examination of how exposure to humid air can result in changes in the adsorption properties of activated carbons. Carbon 26, 451-459.

Albers, P.W., Klein, H., Lox, E.S., Seibold, K., Prescher, G., Parker, S.F., 2000. INS-, SIMS- and XPS-investigations of diesel engine exhaust particles. Physical Chemistry Chemical Physics 2, 1051-1058.

Baldock, J.A., Smernik, R.J., 2002. Chemical composition and bioavailability of thermally altered Pinus resinosa (Red pine) wood. Organic Geochemistry 33, 1093-1109.

Billinge, B.H.M., Evans, M.G., 1984. The growth of surface oxygen complexes on the surface of activated carbon exposed to moist air and their effect on methyl Iodide-131 retention.
Journal de Chimie Physique et de Physico-Chimie Biologique 81, 779-784.

Bird, M.I., Moyo, C., Veenedaal, E.M., Lloyd, J., Frost, P., 1999. Stability of elemental carbon in a savanna soil. Global Biogeochemical Cycles 13, 923-932.

Boehm, H.P., 1966. Functional groups on the surfaces of solids. Angewandte Chemie 5, 533-622.

Boehm, H.P., 1994. Some aspects of surface chemistry of carbon blacks and other carbons. Carbon 32, 759-770.

Bradbury, A.G.W., Shafizadeh, F., 1980. Chemisorption of oxygen on cellulose char. Carbon 18, 109-116.

Chughtai, A.R., Kim, J.M., Smith, D.M., 2003. The effect of temperature and humidity on the reaction of ozone with combustion soot: implications for reactivity near the tropopause. Journal of Atmospheric Chemistry 45, 231-243.

Cody, G.D., Alexander, C.M., 2005. NMR studies of chemical structural variation of insoluble organic matter from different carbonaceous chondrite groups. Geochimica et Cosmochimica Acta 69, 1085-1097.

Fakoussa, R.M., Hofrichter, M., 1999. Biotechnology and microbiology of coal degradation. Applied Microbiology and Biotechnology 52, 25-40.

Glaser, B., Haumaier, L., Guggenberger, G., Zech, W., 2001. The 'Terra Preta' phenomenon: a model for sustainable agriculture in the humid tropics. Naturwissenschaften 88, 37-41.

Glaser, B., Lehmann, J., Zech, W., 2002. Ameliorating physical and chemical properties of highly weathered soils in the tropics with charcoal - a review. Biology and Fertility of Soils $35,219-230$.

Goldberg, E.D., 1985. Black Carbon in the Environment: Properties and Distribution. Wiley, New York.

Guo, Y., Bustin, R.M., 1998. FT-IR spectroscopy and reflectance of modern charcoals and fungal decayed woods: implications for studies of inertinite in coals. International Journal of Coal Geology 37, 29-53.

Hamer, U., Marschner, B., Brodowski, S., Amelung, W., 2004. Interactive priming of black carbon and glucose mineralisation. Organic Geochemistry 35, 823-830.

Kawamoto, K., Ishimaru, K., Imamura, Y., 2005. Reactivity of wood charcoal with ozone. Journal of Wood Science 51, 66-72.

Kuhlbusch, T.A.J., Crutzen, P.J., 1995. Toward a global estimate of black carbon on residues of vegetation fires representing a sink of atmospheric $\mathrm{CO}_{2}$ and a source of $\mathrm{O}_{2}$. Global Biogeochemical Cycles 9, 491-501.

Laszlo, K., Tombacz, E., Kerepesi, P., 2004. Surface chemistry of nanoporous carbon and the effect of $\mathrm{pH}$ on adsorption from aqueous phenol and 2,3,4-trichlorophenol solution. Collids and Surfaces A: Physicochemical and Engineering Aspects 230, 13-22.

Lau, A.C., Furlong, D.N., Healy, T.W., Grieser, F., 1986. The electrokinetic properties of carbon black and graphitized carbon black aqueous colloids. Colloids and Surfaces 18, 93104.

Lehmann, J., Rondon, M., 2006. Bio-char soil management in highly weathered soils in the humid tropics. In: Uphoff, N. (Ed.), Biological Approaches to Sustainable Soil Systems. CRC Press, Boca Raton, FL, pp. 517-530.

Lehmann, J., da Silva, J.P., Rondon, M., Cravo, M.S., Greenwood, J., Nehls, T., Steiner, C., Glaser, B., 2002. Slash-andchar: a feasible alternative for soil fertility management in the central Amazon? In: Seventeenth World Congress of Soil Science, Bangkok, Thailand. Paper no. 449, pp. 1-12. 
Lehmann, J., Liang, B., Solomon, D., Lerotic, M., Luizao, F., Kinyangi, J., Schäfer, T., Wirick, S., Jacobsen, C., 2005. Near-edge X-ray absorption fine structure (NEXAFS) spectroscopy for mapping nano-scale distribution of organic carbon forms in soil: Application to black carbon particles. Global Biogeochemical Cycles 19, GB1013. doi:10.1029/ 2004GB002435.

Liang, B., Lehmann, J., Solomon, D., Kinyangi, J., Grossman, J., O’Neill, B., Skjemstad, J.O., Thies, J., Luizão, F.J., Petersen, J., Neves, E.G., 2006. Black carbon increases cation exchange capacity in soils. Soil Science Society of America Journal, in press.

Machnikowska, H., Pawelec, K., Podgo'rska, A., 2002. Microbial degradation of low rank coals. Fuel Processing Technology 77-78, 17-23.

Martinez, C.E., Jacobson, A., McBride, M.B., 2001. Thermally induced changes in metal solubility of contaminated soils is linked to mineral recrystallization and organic matter transformation. Environmental Science and Technology 35, 908916.

Mattson, J.S., Mark, H.B., 1971. Activate Carbon: Surface Chemistry and Adsorption from Solution. Marcel Dekker, New York.

Mawhinney, D.B., Yates, J.T., 2001. FT-IR study of the oxidation of amorphous carbon by ozone at $300 \mathrm{~K}$ - direct $\mathrm{COOH}$ formation. Carbon 39, 1167-1173.

Moreno-Castilla, C., Lopez-Ramon, M.V., Carrasco-Marin, F., 2000. Changes in surface chemistry of activated carbons by wet oxidation. Carbon 38, 1995-2001.

Morterra, C., Low, M.J.D., 1982. The nature of the $1600 \mathrm{~cm}^{-1}$ band of carbons. Spectroscopy Letters 15, 689-697.

Morterra, C., Low, M.J.D., Severdia, A.G., 1984. IR studies of carbon. 3. The oxidation of cellulose chars. Carbon 22, 5-12.

Petsch, S.T., Eglington, T.I., Edwards, K.J., 2001. ${ }^{14}$ C-dead living biomass: evidence for microbial assimilation of ancient organic carbon during shale weathering. Science 292, 1127 1131 .

Pittman, C.U., Jiang, W., Yue, Z.R., Gardner, S., Wang, L., Tohiani, H., Leon, C.A.L.Y., 1999. Surface properties of electrochemically oxidized carbon fibers. Carbon 37, 17971807.

Proctor, A., Sherwood, P., 1982. XPS studies of carbon fiber surface. Surface and Interface Analysis 4, 213.

Puri, B.R., 1963. Surface oxidation of charcoal at ordinary temperatures. In: Proceedings of the Fifth Carbon Conference. Symposium Publications Division, Pergamon Press, Buffalo, NY, pp. 165-170.
Puri, B.R., 1970. Chemistry and physics of carbon. In: Walker, P.L., Jr.Jr. (Ed.), Chemistry and Physics of Carbon. Marcel Dekker, New York, pp. 191-282.

Puri, B.R., Sharma, S.K., 1968. Studies in the formation and properties of carbon-oxygen surface complexes: part II. Nature of the surface complexes formed on progressive treatment with oxidising solutions. Journal of the Indian Chemical Society 45, 1115-1119.

Rideal, E.K., Wright, W.V., 1925. Low temperature oxidation at charcoal surface. Part I. The behaviour of charcoal in the absence of promoters. Journal of the Chemical Society 127 , 1347-1357.

Schmidt, M.W.I., Noack, A.G., 2000. Black carbon in soils and sediments: analysis, distribution, implications, and current challenges. Global Biogeochemical Cycles 14, 777-793.

Sergides, C.A., Jassim, J.A., Chughtai, A.R., Smith, D.M., 1987. The structure of hexane soot. Part III: ozonation studies. Applied Spectroscopy 41, 482-492.

Shindo, H., 1991. Elementary composition, humus composition and decomposition in soil of charred grassland plants. Soil Science and Plant Nutrition 37, 651-657.

Shneour, E.A., 1966. Oxidation of graphitic carbon in certain soils. Science 151, 991-992.

Skjemstad, J.O., Clarke, P., Taylor, J.A., Oades, J.M., McClure, S.G., 1996. The chemistry and nature of protected carbon in soil. Australian Journal of Soil Research 34, 251-276.

Sombroek, W.G., Nachtergaele, F.O., Hebel, A., 1993. Amounts, dynamics and sequestering of carbon in tropical and subtropical soils. Ambio 11, 417-426.

Teng, H., Hsieh, C-T., 1999. Activation energy for oxygen chemisorption on carbon at low temperatures. Industrial and Engineering Chemistry Research 38, 292-297.

Toles, C.A., Marshall, W.E., Johns, M.M., 1999. Surface functional groups on acid-activated nutshell carbon. Carbon $38,1207-1214$.

Tryon, E.H., 1948. Effect of charcoal on certain physical, chemical, and biological properties of forest soils. Ecological Monographs 18, 81-115.

van der Marel, H.M., Beutelspacher, H., 1976. Atlas of Infrared Spectroscopy of Clay Minerals and their Admixtures. Elsevier Scientific Pub., New York.

Willmann, G., Fakoussa, R.M., 1997. Biological bleaching of water-soluble coal macromolecules by a basidiomycete strain. Applied Microbiology and Biotechnology 47, 95-101.

Yang, Y., Sheng, G., 2003. Pesicide adsorptivity on aged particulate matter arising from crop residue burns. Journal of Agricultural and Food Chemistry 51, 5047-5051. 